ISSN: 2146-3042

DOI:

\title{
İşletmelerin Çevresel Yaklaşımları Ve Çevre Muhasebesine Verdikleri Önem: Ordu İl Ve İlçelerindeki Organize Sanayi Bölgeleri Üzerine Bir Araştırma*
}

Neşegül PARLAK*

\section{ÖZET}

İşletmelerin hedeflerine ulaşmak amacıyla gerçekleştirdikleri faaliyetlerin çevreye olan zararlı etkileri kaçınllmazdir. İşletmeler, çevreyi korumaya yönelik yasal düzenlemeleri ve çevreye duyarlı tüketici anlaylşııı göz ardı ederek faaliyetlerini yürütemeyeceklerinden, bu etkileri dikkate almaksızın basarll olmaları da mümkün değildir. Bu nedenle, bahsi geçen zararlı etkileri önlemeye yönelik olarak yapacakları ek yatırımlar ve bu yatırımlar nedeniyle katlanacakları ek maliyetler söz konusu olmaktadır. Bu yatırımlardan kaynaklanan ek maliyet bedeli, ișletmelerin muhasebe bilgi sisteminden elde ettikleri raporlar ile belirlenebilmektedir. Çevre muhasebesi (ÇM), işletmelerin çevre ile olan ilişkilerinde almış oldukları önlemlerin muhasebeleştirilmesi ile elde edilen verilerden oluşan raporun işletme sahiplerine sunulmasın sağlayan sistemdir.

$B u$ çalışma, işletmelerin çevresel yaklaşımlarını ve çevre muhasebesinin önemine iliş̧kin algı ve tutumlarını tespit etmek amacıyla Ordu ili ve merkez ilçelerindeki organize sanayi bölgelerinde faaliyet gösteren işletme yöneticilerine anket uygulamak suretiyle yapılmıştır. Çalışma sonucunda, işletme yöneticilerinin çevresel yaklaşımları ve çevre muhasebesinin önemine ilişkin yaklaşımları yüksek düzeyde benimsedikleri tespit edilmiştir. Ayrıca, işletme yöneticilerinin çevresel yaklaşımlart ile çevre muhasebesine verdikleri önem arasında pozitif yönlü ve anlamlı ilişki tespit edilmiştir.

Anahtar Kelimeler: Çevre, Çevre Muhasebesi, Çevresel Yaklaşımlar.

JEL Sinıflandırması: M41

Environmental Approaches Of Enterprises And The Importance They Attach To Environmental Accounting: A Survey On Organized Industrial Zones In Ordu Province And Districts

\section{ABSTRACT}

The harmful effects of the activities performed by enterprises to reach their targets are inevitable. Since the enterprises will not be able to perform their activities by ignoring the legal regulations to protect the environment and the environmentally sensitive consumer understanding, they cannot succeed without considering these effects. Therefore, additional investments to prevent the harmful effects mentioned above and the additional costs incurred due to these investments are in question. Additional costs value incurred from these investments can be determined by the reports obtained from the accounting information system of the enterprises. Environmental accounting (MIS) is the system that enables presentation to the business owners the report consisting of the data obtained by accounting for the measures taken by the enterprises in their relations with the environment.

This study was conducted by applying a questionnaire to the business managers operating in organized industrial zones in Ordu province and its central districts in order to determine the environmental approaches of enterprises and their perceptions and attitudes about the importance of environmental accounting. As a result of the study, it has been determined that business managers adopt high approaches to environmental approaches and the importance of environmental accounting. In addition, a positive and significant relationship was found between the environmental management of business managers and their importance in environmental accounting.

Keywords: Environment, Environmental Accounting, Environmental Approaches.

Jel Classification: $M 41$

* Makale Gönderim Tarihi: 02.07.2019, Makale Kabul Tarihi: 21.10.2019,Makale Türü: Araştırma Makalesi

* Öğr. Gör. Dr., Ordu Üniversitesi Fatsa Meslek Yüksekokulu, nparlak@odu.edu.tr, Orcid ID: 0000-0002-16697389. 


\section{GíRiş}

İşletmeler, sınırsız insan ihtiyaçlarını karşılamak üzere mal ve hizmet üretme sürecinde çevreden çeşitli şekillerde yararlanmakta ve doğal kaynakları kullanmaktadır (Alagöz ve Yılmaz, 2001:149). Çevrenin ve çevresel maliyetlerin etkili yönetimi işletmelerin rekabet avantajı elde etmeleri ve başarılı olmaları açısından çok önemli bir unsurdur. Dolayısıyla, işletmeler artık faaliyetlerinin çevresel boyutunu görmezden gelemezler. $\mathrm{Bu}$ nedenle, işletmelerin, çevreye duyarlı yatırımlara ve teknolojilere yönelmesi kaçınılmaz hale gelmiş̧ir. Geleneksel muhasebe süreçleri, çevresel maliyetlerin işletme tarafindan ne kadar etkili bir şekilde yürütüldüğünün yönetimce belirlenerek izlenmesine ve süreç içerisinde sağlanan bilgilerin yönetimin karar verme aşamasında göz önünde bulundurulmasına tam olarak imkân vermemektedir. Çevre muhasebesi (ÇM), işletme faaliyetlerinin çevreye vereceği zararları önlemeye yönelik yatırım ve işlemlerden doğacak ek maliyetlerin doğru olarak tespit edilmesi, hesaplanması, izlenmesi ve çevresel etkinliğin ölçülmesi ve iyileştirilmesinin sağlanarak ilgi duyan taraflara düzenli olarak raporlanması açısından önemli bir sistemdir.

\section{2. ÇEVRE MUHASEBESI}

Çevre, insanın üretim ve yaşama kaynağını oluşturan doğal ortam koşullarına sosyal koşulların ilavesi (Dura, 1991: 68) şeklinde tanımlanabilir. Başka bir tanımlamaya göre çevre, işletme faaliyetlerini ve gelişim süreçlerini etkileyen işletme içinden ve dışından gelen şartlar ve etkiler sistemidir (Yörük, 1999: 68).

Çevre muhasebesi, gerek geleneksel gerekse de çevre yönetimi ile ilgili karar almada kullanılmak amacıyla üretim sürecine ilişkin bilgilerin, çevresel maliyetlerin tespit edilmesi, analiz edilmesi ve hem işletme içi hem de işletme dışı ilgililere raporlanması faaliyetlerinin bütünü olarak ifade edilebilir. Çevre muhasebesi, işletmenin faaliyetlerinden doğan ancak sorumluluk kapsamına girmeyen maliyetleri de kapsamaktadır (Özbirecikli, 2002: 26).

Çevre muhasebesinin temel amaçlarını aşağıdaki gibi sıralayabiliriz (Özay Baltacı, 2009: 31):

- Bilgi sağlamak,

- Kaynak envanteri çıarmak,

- Malzeme maliyetlerinin, faaliyet kar veya zararının doğru ve güvenilir biçimde hesaplanmasina yardımci olmak,

- Artan rekabet koşullarına uyum sağlamak,

- Çevresel performansin arttırılmasına yardımcı olmak.

İşletmeler, çevreye verdikleri zararı önlemeye, azaltmaya ya da tamamen gidermeye yönelik yürüttükleri etkinlikler nedeniyle ek maliyetlere katlanmak durumunda kalırlar. İşletme faaliyetlerinin çevreye olan etkilerinin artması ve bu etkilerinin sonuçlarıyla ilgilenen tarafların, işletmenin çevresel performansını iyileştirmesini ve raporlama yapılması 
konusundaki baskılarının gitgide artması ve bu baskıların bir sonucu olarak çevreyle ilgili maliyetlerin, gelirlerin ve faydaların öneminin artması ile çevresel unsurlar örgütsel karar alma süreçlerinin önemli birer parçası haline gelmiş̧ir (Gale, 2006 :1230).

Çevresel muhasebe sistemi ile işletme faaliyetlerinin çevreye olan zararları azaltırken maliyet tasarrufu sağlanacak ve işletmeler hem finansal hem de ekonomik performansını arttırarak rekabet avantaj elde edeceklerdir. Çevre muhasebesi sisteminin işletmelere sağlayacağı faydalar aşağıdaki gibi sıralanabilir:

Malzemelerin geri dönüşümünden ya da atıkların başka bir takım faaliyetlerde kullanılması yoluyla gelir elde edilmesi gibi daha önceden saptanmamış, gizli kalmış bir takım gelir artırıcı firsatların ortaya çıkarılmasını kolaylaştırabilir.

Çevresel maliyetlerin kesin ve dikkatli bir şekilde saptanması, ürün fiyatlandırma, ürün karmasının belirlenmesi ve ürün geliştirme sürecinde rehber niteliği taşıyacak bilgileri sağlar.

Çevre muhasebesi kapsamında elde edilen bilgiler, işletmenin çevresel faaliyetleri önem derecelerine göre sıralama imkânı vermektedir.

Çevresel maliyetlerin hesaplanması, işletmelere faaliyetlerinin çevresel etkileri ile ilgili veri toplamada kolaylık sağlayarak; içsel ve dışsal raporlamaya yardımcı olur.

Çevre muhasebesi sistemi, çevreyle ilgili yasal düzenlemelere ve işletmenin kendisinin belirlediği politikalara uyumda maliyet etkinliğini sağlayarak; çevrenin korunmasına yönelik çabaları destekler.

- İşletmenin; faaliyetlerinin çevresel etkilerini yönetme ve azaltma çabaları, çalışanları üzerinde olumlu bir etki bırakarak, işletmeye olan bağllıklarının da artmasına katkıda bulunabilecektir. bulunacaktır.

$\mathrm{Bu}$ çabalar aynı zamanda toplumda işletme itibarının da artmasına katkıda

Daha temiz bir çevre için işletmenin çevresel maliyetlerini ve etkilerini azaltma çalışmaları, ayrıca insanların ve toplumun da elde ettikleri faydayı artıracaktır.

İşletme faaliyetlerinin sürdürülebilirliğinin değerlendirilmesinde ve sağlanmasında yardımcı olur.

\section{1. Çevre Muhasebesi Sisteminin Ortaya Çıkışı}

Giderek artan dünya nüfusu ile ülkelerde yaşanan teknolojik gelişmeler ile birlikte hava kirliliği, küresel ısınma, yeşil alanların azalması, gürültü kirliliğinin artması, kimyasal ve radyoaktif atıklar gibi çevresel sorunlar baş göstermeye başlamıştır (Xiaomei, 2004:48). Gittikçe artan bu çevresel sorunlar, birçok ülke yönetiminin dikkatini, işletme faaliyetlerinin çevre üzerindeki etkilerine yoğunlaştırmalarına ve çevresel maliyetlerin tespit edilmesine, çevresel bilgilerin tüm ilgilerinin ihtiyaçlarını karşılayacak şekilde raporlanması gibi konularda işletme üzerindeki baskılarını artırmalarına neden olmuştur (Burritt, 2004: 23). İşletmeler ise faaliyetlerinin çevre üzerindeki zararları önlemeye yönelik tedbirlerin alınması ile sürdürülebilirliğinin sağlanması amacıyla finansal performanslarının yanında çevresel performanslarını da geliştirmek amacıyla yeni yöntemler geliş̧irmişlerdir.

Çevre muhasebesi; işletme faaliyetlerinin çevreye olan zararlarının azaltılması ve üretim verimliliğinin arttırılması amaçlarıyla finansal muhasebe ile maliyet muhasebesi verilerinin bütünleştirilmesini sağlayan bir sistemi ifade etmektedir (Jasch, 2003:668). 
Geleneksel muhasebe sisteminde, işletmelerin önemli çevresel maliyetleri (boşa harcanan malzeme ve enerji vb) muhasebe kayıtlarında göz ardı etmeleri yönetim kararlarında çevresel maliyetlerin etkinliği hakkında bilgi sahibi olmamaları ve bu maliyetleri düşürmek için bir çaba sarf etmemeleri sonucunu doğurmaktadır (Xiaomei, 2004:50). Yöneticilere planlama, karar alma ve kontrol faaliyetlerine yönelik olarak ihtiyaç duydukları bilgiyi sağlarken; çevresel maliyetlerin ayrı bir başlık altında tanımlanmaması, sınıflandırılmaması, ölçümlenmemesi ve raporlanmaması, çevresel konular ile ilgili olarak geleneksel yönetim muhasebesinin en önemli yetersizliğini oluşturduğu görülmektedir (Burritt, 2004: 14). Geleneksel muhasebe sisteminin çevresel konulara ilişkin karar alma süreçlerindeki bu yetersizlikleri, çevresel muhasebe yaklaşımının ortaya çıkmasına neden olmuştur (Gale, 2006:1230).

İşletmeler, çevresel muhasebe ile maliyetlerini azaltıp; karlılıklarını artırırken aynı zamanda faaliyetlerinin çevre üzerindeki olumsuz etkilerini en aza indirebileceklerdir (Akbaş, 2011: 53). Çevresel muhasebe uygulamaları ile sağlanan parasal ve fiziki bilgiler, işletmelerin hem finansal hem de çevresel performansını arttıracak kararların alınmasında bir rehber hizmeti görmektedir (Xiaomei, 2004: 50). Çevresel muhasebe, şirketlere yalnız üretim süreçlerindeki çevresel maliyetleri tanımlama ve ölçmeye yardım etmekle kalmaz aynı zamanda çevresel performans açıklamalarını sürdürmek amacıyla doğru maliyet bilgilerini oluşturan uygun muhasebe yaklaşımıdır (Kaya, 2016: 27).

\section{2. Çevre Muhasebesi İle İlgili Literatür}

Ulusal ve uluslararası literatür incelendiğinde çevresel muhasebe sistemini konu alan çok sayıda çalışma bulunmaktadır. Bu çalışmalardan bazılarına aşağıda yer verilmiştir:

\begin{tabular}{|c|c|}
\hline Yazar (Yıl) & Konu \\
\hline Güvemli ve Gökdeniz (1996) & Çevre muhasebesindeki gelişmeler \\
\hline Schaltegger vd. (2000) & Çevresel muhasebe kavramları, uygulama ve sorunlar \\
\hline Özbirecikli (2002) & Çevresel maliyetlerin, maliyet gruplarındaki payı, \\
\hline Yüksel (2003) & $\begin{array}{l}\text { İşletmelerin çevreye duyarlı üretim faaliyetlerinin, çevre performansına ve } \\
\text { işletme performansına olan etkisi, }\end{array}$ \\
\hline Yakhou ve Dorweiler (2004) & İşletme stratejisinin belirlenmesinde çevrenin önemi, \\
\hline Gönel ve Atabarut (2005) & İşletmelerde çevre muhasebesinin uygulanışı (farklı ülke örnekleri), \\
\hline Kirlıŏlu ve Can (2006) & $\begin{array}{l}\text { Çevre muhasebesindeki kavramsal tartışmaların gelişimi ve analizi, gelecekte } \\
\text { yapılması gerekenler, }\end{array}$ \\
\hline Aslanertik ve Özgen (2007) & Otel işletmelerinde çevre muhasebesinin önemi ve uygulanışı, \\
\hline Çelik (2007) & Çevreye duyarlı muhasebe sisteminin incelenmesi \\
\hline Çakar (2007) & Çevreye duyarlı muhasebe sisteminin çevreci şirket yönüyle incelenmesi \\
\hline Lazol ve diğer., (2008) & Çevre muhasebesinin KOBİ'lerde uygulanışı \\
\hline Akatay ve Aslan (2008) & $\begin{array}{l}\text { İşletmelerin yeşil yönetime duyarlılıkları ve bu kapsamda işletmeleri ISO } \\
14001 \text { sertifikası almaya yönelten faktörler }\end{array}$ \\
\hline
\end{tabular}




\begin{tabular}{|l|l|}
\hline Cavlı (2009) & İşletmelerin çevresel sorumluluk çalışmaları \\
\hline Soylu ve İleri (2009) & Çevre muhasebesi ve çevre maliyetlerinin üretim maliyetlerine etkileri \\
\hline Bengü ve Can (2009) & Çevre muhasebesinin tarihi \\
\hline Korukoğlu (2011) & Çevre muhasebesinin işletmelerde uygulanış şekli ve karşılaşılan sorunlar, \\
\hline Deniz ve Türker (2012) & Çevresel muhasebe uygulamaları (Ormancllık sektörü üzerine araştırma), \\
\hline Alagöz ve İrdiren (2013) & İşletmelerde çevre maliyetleri ve yönetimi, \\
\hline Korukoğlu (2014) & İşletmelerin çevre muhasebesi konularına yaklaşımları, \\
\hline Orhan ve Ağ (2017) & $\begin{array}{l}\text { Üretim işletmelerinin çevre muhasebesine verdikleri önem düzeyi: Erzurum, } \\
\text { Erzincan, Bayburt Bölgesinde Bir Araştırma }\end{array}$ \\
\hline Saban ve diğer., (2018) & Çevresel muhasebe açısından reklamasyon maliyetlerinin raporlanması \\
\hline
\end{tabular}

\section{ISSLETMELERIN ÇEVRESEL YAKLAŞIMLARI VE ÇEVRE MUHASEBESINE VERDIKLERI ÖNEM: ORDU İLİ VE MERKEZ İLÇELERI ORGANIZE SANAYİ BÖLGELERİ (OSB) ARAŞTIRMASI}

Araştırmada, işletmelerin çevresel yaklaşımları ve çevre muhasebesine verdikleri önem ordu ili ve merkez ilçelerindeki organize sanayi bölgelerindeki işletme yöneticileri üzerine gerçekleştirilen ölçek çalışması ile değerlendirilmiştir.

\subsection{Araştırmanın Amacı ve Kapsamı}

$\mathrm{Bu}$ araştırmada, işletmelerin çevresel yaklaşımları ve çevre muhasebesine yönelik algılarını tespit etmek amaçlanmıştır. Bu amaçla, Ordu ili ve merkez ilçelerindeki organize sanayi bölgelerinde faaliyet gösteren işletmeler üzerine ölçek uygulaması yapılmıştır.

Araştırmanın ana kütlesini, Ordu ili ve merkez ilçelerinde bulunan organize sanayi bölgelerinde faaliyet gösteren tüm işletmeler oluşturmaktadır. Bu bölgelerde faaliyet gösteren işletmelerin sayısı 131'dir. İşletme yöneticileri ile yüz yüze gerçekleştirilen ölçek çalışmasında 117 işletme yöneticisinden cevap alınabilmiştir. Elde edilen ölçek formlarından 5'i veri eksikliği sebebiyle değerlendirme diş1 tutularak, 112 ölçek formu analize dâhil edilmiştir. $\mathrm{Bu}$ çerçevede ölçek formlarının geri dönüş oranı \% 85 olarak hesaplanmıştır. Araştırma verileri Ocak-Nisan 2019 döneminde elde edilmiştir.

\subsection{Araştırmanın Veri Toplama Yöntemi ve Analiz}

Araştırmada, veri toplama aracı olarak, Çetin (2011) tarafından geliştirilen ölçek formu kullanılmıştır. Üç bölümden oluşan ölçek formunun ilk bölümünde işletmenin faaliyet alanı, faaliyet süresi, işletmede çalışan personel sayısı, işletme büyüklüğü, çevresel maliyet durumu, çevresel sorunları önlemeye yönelik yatırım durumu ve yatırımların zorunlulukgönüllülük durumu, yatırımların gerçekleştirilmesinde mali destek alma durumu bilgilerinden oluşan işletmeye ilişkin bilgi formu yer almaktadır. 
Anket formunun ikinci bölümünde "Çevreyle İlgili Yaklaşımlar Ölçeği” yer almaktadır. Ölçekte iki madde $(\mathrm{m} 3, \mathrm{~m} 7)$ ters kodlanmakta olup yüksek puan işletmenin çevresel yaklaşımları benimsediğini ifade etmektedir. Bu çalışmada ölçeğin Cronbach Alpha katsayısı 0,83 olarak tespit edilmiştir.

Ölçek formunun üçüncü bölümünde "Çevre Muhasebesi ile İlgili Yaklaşımlar Ölçeği”" yer almaktadır. Ölçekte iki madde $(\mathrm{m} 2, \mathrm{~m} 11)$ ters kodlanmakta olup yüksek puan işletme muhasebesinin çevreden sorumlu olması gerektiği yaklaşımının benimsendiğini ifade etmektedir. Bu çalışmada ölçeğin Cronbach Alpha katsayısı 0,85 olarak tespit edilmiştir.

Araştırmada, ölçek uygulamasının tercih edilme nedeni verilerin toplanma sürecinde zaman ve maliyet tasarrufu sağlaması, ayrıca analiz kolaylığı sağlaması ve görüşmeci kaynaklı önyargı etkisinin bulunmamasıdır.

\subsection{Araştırma Bulguları ve Tartışma}

Veriler, SPSS 16.0 programı kullanılarak analiz edilmiştir. Araştırmada, işletmenin çevresel maliyet durumu, çevresel sorunları önlemeye yönelik yatırım durumu ve yatırımların zorunluluk-gönüllülük durumu, yatırımların gerçekleştirilmesinde mali destek alma durumu değişkenlerine göre karşılaştırılmasında bağımsız iki örneklem t testinden; işletmenin faaliyet alanı, faaliyet süresi, işletmede çalışan personel sayısı, işletme büyüklüğü değişkenlerine göre karşılaştırılmasında ANOVA testinden yararlanılmıştır. ANOVA testinde anlamlı farklılık görüldügüünde farkın hangi gruplar arasında olduğunu belirlemek amacıyla LSD post hoc testi kullanılmıştır. Ölçek puanları arasındaki ilişki analizinde Pearson korelasyonu kullanılmıştır. Analizlerde güven aralığ $\% 95$ (anlamlılık düzeyi $0,05 \mathrm{p}<0,05$ ) olarak belirlenmiştir.

Tablo 1. İşletmeye İlişkin Bilgilerin Dağglımı

\begin{tabular}{llll}
\hline & Gruplar & $\mathbf{n}$ & $\mathbf{\%}$ \\
\hline & Gida & 29 & 25,9 \\
& Tekstil & 22 & 19,6 \\
İşletmenin faaliyet alanı & İşaat & 16 & 14,3 \\
& Sanayi mamulü & 24 & 21,4 \\
& Otomotiv & 13 & 11,6 \\
& Diğer & 8 & 7,1 \\
\hline \multirow{3}{*}{ İşletmenin faaliyet süresi } & $1-5$ yıl & 21 & 18,8 \\
& 6-10 yıl & 42 & 37,5 \\
& 11 yıl ve üstü & 49 & 43,8 \\
\hline \multirow{3}{*}{ I̧şletmedeki çalışan sayısı } & $1-20$ kişi & 32 & 28,6 \\
& $21-30$ kişi & 21 & 18,8 \\
& $31-50$ kişi & 21 & 18,8 \\
& $51-100$ kişi & 19 & 17,0 \\
\hline I̧şletme büyüklüğü & 101 kişi ve üstü & 19 & 17,0 \\
\hline
\end{tabular}




\begin{tabular}{llll} 
& Orta & 81 & 72,3 \\
& Büyük & 16 & 14,3 \\
\hline \multirow{2}{*}{ Çevresel maliyetlerin varlı̆̆ı } & Evet & 90 & 80,4 \\
& Hayır & 22 & 19,6 \\
\hline Çevresel sorunları önlemeye yönelik & Evet & 84 & 75,0 \\
yatırım & Hayır & 28 & 25,0 \\
\hline Çevresel sorunlara yönelik & Zorunlu & 62 & 73,8 \\
yatırımların nedeni (N=84) & Gönüllü & 22 & 26,2 \\
\hline Çevresel sorunlara yönelik yatırımlar & Evet & 21 & 25,0 \\
için mali destek alma (N=84) & Hayır & 63 & 75,0
\end{tabular}

Tablo 1'de işletmeye ilişkin bilgilere göre frekans ve yüzde dağılımı gösterilmiştir. Araştırmaya 112 işletmenin $\% 25,9$ 'u gıda, \%19,6'sı tekstil, \%14,3'ü inşaat, \%21,4'ü sanayi mamulü, \%11,6's1 otomotiv, \%7,1'i diğer sektörlerde faaliyet göstermektedir. İșletmelerin $\% 18,8$ 'inin faaliyet süresi $1-5 \mathrm{y} 11, \% 37,5$ 'inin $6-10 \mathrm{y} 1, \% 43,8$ 'inin faaliyet süresi 11 y1l ve üstüdür. İşletmelerin \%28,6'sında çalışan sayısı 1-20 kişi, \%18,8'inde 21-30 kişi, $\% 18,8$ 'innde $31-50$ kişi, \%17'sinde 51-100 kişi, \%17'sinde 101 kişi ve üstüdür. İşletmelerin $\% 13,4$ 'ü küçük çaplı, \%72,3'ü orda düzeyde, \%14,3'ü büyük çaplı bir işletme olarak tanımlanmaktadır. İşletmelerin \%80,4'ünde çevresel maliyet, \%75'inde çevresel sorunları önlemeye yönelik yatırım bulunmaktadır. Çevresel sorunları önlemeye yönelik yatırım yapan işletmelerin $(\mathrm{N}=84) \% 73,8$ 'i zorunlu olarak, \%26,2'si gönüllü olarak yatırım yapmıştır. Çevresel sorunları önlemeye yönelik yatırım yapan işletmelerin $(\mathrm{N}=84) \% 25$ 'i bu yatırımları gerçekleştirirken teşvik / kredi kolaylı̆̆ı / hibe gibi mali destek almıştır (Tablo 1).

Tablo 2. Ölçek Puanlarına Ait Betimsel İstatistikler

\begin{tabular}{lllllll}
\hline Ölçek & $\mathbf{n}$ & Min. & Maks. & $\overline{\mathbf{x}}$ & SS & Skewness \\
\hline Çevreyle İlgili Yaklaşımlar & 112 & 3,00 & 5,00 & 4,18 & 0,53 & 0,07 \\
\hline $\begin{array}{l}\text { Çevre Muhasebesinin } \\
\text { Önemine İlişkin Yaklaşımlar }\end{array}$ & 112 & 2,30 & 4,70 & 3,87 & 0,43 & $-0,30$ \\
\hline$* * p<0,01$ & & & & & &
\end{tabular}

Tablo 2'deki ölçek puanlarının ortalama, standart sapma ve çarpıklık (Skewness) bilgilerinden oluşan betimsel istatistiklerine göre, çevreyle ilgili yaklaşımlar ölçek puanı $4,18 \pm 0,53$ olarak tespit edilmiş olup alınabilecek en düşük (1) ve en yüksek (5) puanlara göre araştırma kapsamındaki işletmelerin çevresel yaklaşımları "yüksek düzeyde" benimsedikleri tespit edilmiştir.

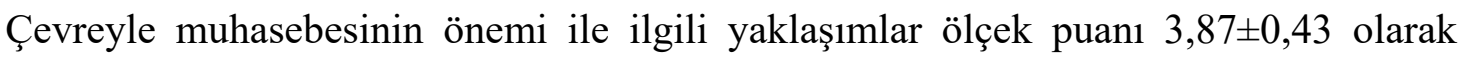
tespit edilmiş olup alınabilecek en düşük (1) ve en yüksek (5) puanlara göre araştırma kapsamındaki işletmelerin işletme muhasebesinin çevreden sorumlu olması gerektiği yaklaşımını "yüksek düzeyde" benimsedikleri tespit edilmiştir. 
Tablo 3. Ölçek Puanlarının İşletmenin Faaliyet Alanına Göre Karşılaştırılmasına Ait ANOVA Testi Sonuçları

\begin{tabular}{llllllll}
\hline Ölçekler & Faaliyet Alanı & $\mathbf{n}$ & $\overline{\mathbf{x}}$ & $\mathbf{S S}$ & $\mathbf{F}$ & $\mathbf{p}$ & Fark \\
\hline & A-Gıda & 29 & 4,29 & 0,55 & & & \\
Çevreyle İlgili & B-Tekstil & 22 & 4,06 & 0,47 & & & \\
Yaklaşımlar & C-İnşaat & 16 & 4,28 & 0,40 & & & \\
& D-Sanayi mamulü & 24 & 4,17 & 0,54 & 0,94 & 0,458 & \\
& E-Otomotiv & 13 & 3,99 & 0,67 & & & \\
& F-Diğer & 8 & 4,28 & 0,60 & & & \\
Çevre & A-Gıda & 29 & 4,01 & 0,38 & & & A,F>B \\
Muhasebesinin & B-Tekstil & 22 & 3,68 & 0,39 & & & \\
Önemine İlişkin & C-İnşaat & 16 & 3,84 & 0,29 & & & \\
Yaklaşımlar & D-Sanayi mamulü & 24 & 3,89 & 0,39 & 2,40 & $\mathbf{0 , 0 4 2}$ & \\
& E-Otomotiv & 13 & 3,76 & 0,70 & & & \\
& F-Diğer & 8 & 4,13 & 0,33 & & & \\
\hline
\end{tabular}

Tablo 3'teki ölçek puanlarının işletmenin faaliyet alanına göre karşılaştırmasına ait tek yönlü varyans analizi (ANOVA) sonuçlarına göre, çevreyle ilgili yaklaşım puanlarının işletmelerin faaliyet alanına göre anlamlı farklılık göstermediği $(p>0,05)$ tespit edilmiştir. Çevre muhasebesinin önemi ile ilgili yaklaşım puanlarının işletmelerin faaliyet alanına göre anlamlı farklılık gösterdiği tespit edilmiştir $(\mathrm{F}=2,40 ; \mathrm{p}<0,05)$. Farkın hangi gruplar arasında olduğunu belirlemek amaciyla yapılan LSD post hoc testi sonuçlarına göre gida ve diğer sektörlerde faaliyet gösteren işletmelerin çevre muhasebesi ile ilgili yaklaşımlar puanı, tekstil sektöründe faaliyet gösteren işletmelerin puanlarına göre anlamlı düzeyde daha yüksektir.

Tablo 4. Ölçek Puanlarının İşletmenin Faaliyet Süresine Göre Karşılaştırılmasına Ait ANOVA Testi Sonuçları

\begin{tabular}{|c|c|c|c|c|c|c|}
\hline Ölçekler & Faaliyet Süresi & $\mathbf{n}$ & $\overline{\mathbf{x}}$ & SS & $\mathbf{F}$ & $\mathbf{p}$ \\
\hline & A-1-5 y1l & 21 & 4,12 & 0,52 & & \\
\hline \multirow{2}{*}{ Çevreyle İlgili Yaklaşımlar } & B-6-10 y1l & 42 & 4,19 & 0,53 & 0,20 & 0,817 \\
\hline & C-11 yıl ve üstü & 49 & 4,21 & 0,55 & & \\
\hline Muhasebesinin & A-1-5 y1l & 21 & 3,79 & 0,54 & & \\
\hline Önemine & B-6-10 yıl & 42 & 3,82 & 0,36 & 1,64 & 0,199 \\
\hline Yaklaşımlar & C-11 yıl ve üstü & 49 & 3,96 & 0,43 & & \\
\hline
\end{tabular}

Tablo 4'teki ölçek puanlarının işletmenin faaliyet süresine göre karşılaştırmasına ait tek yönlü varyans analizi (ANOVA) sonuçlarına göre, çevreyle ilgili yaklaşım puanlarının 
işletmelerin faaliyet süresine göre anlamlı farkl1lık göstermediği $(p>0,05)$ tespit edilmiştir. Çevre muhasebesinin önemi ile ilgili yaklaşım puanlarının işletmelerin faaliyet süresine göre anlamlı farklılık göstermediği $(\mathrm{p}>0,05)$ tespit edilmiştir.

Tablo 5. Ölçek Puanlarının İşletmedeki Çalışan Sayısına Göre Karşılaştııılmasına Ait ANOVA Testi Sonuçları

\begin{tabular}{llllllll}
\hline \multirow{2}{*}{ Ölçekler } & Çalışan Sayısı & $\mathbf{n}$ & $\overline{\mathbf{X}}$ & $\mathbf{S S}$ & $\mathbf{F}$ & $\mathbf{p}$ & $\begin{array}{l}\text { Anlamlı } \\
\text { Fark }\end{array}$ \\
\hline \multirow{3}{*}{ Çevreyle } & A-1-20 kişi & 32 & 3,95 & 0,51 & & & B,C>A,D \\
Yaklaşili & B-21-30 kişi & 21 & 4,47 & 0,49 & & & \\
& C-31-50 kişi & 21 & 4,40 & 0,51 & 5,26 & $\mathbf{0 , 0 0 1}$ & \\
& D-51-100 kişi & 19 & 3,99 & 0,47 & & & \\
Çevre & E-101 kişi ve üstü & 19 & 4,20 & 0,49 & & & \\
Muhasebesinin & A-1-20 kişi & 32 & 3,81 & 0,50 & & & \\
Önemine & B-21-30 kişi & 21 & 3,95 & 0,42 & & & \\
Yaklişkin & C-31-50 kişi & 21 & 3,94 & 0,37 & 1,25 & 0,292 & \\
& D-51-100 kişi & 19 & 3,73 & 0,40 & & & \\
\hline & E-101 kişi ve üstü & 19 & 3,97 & 0,40 & & & \\
\hline
\end{tabular}

Tablo 5'teki ölçek puanlarının işletmedeki çalışan sayısına göre karşılaştırmasına ait tek yönlü varyans analizi (ANOVA) sonuçlarına göre, çevreyle ilgili yaklaşım puanlarının işletmedeki çalışan sayısına göre anlamlı farklılık gösterdiği tespit edilmiştir ( $\mathrm{F}=5,26$; $\mathrm{p}<0,05)$. Farkın hangi gruplar arasında olduğunu belirlemek amacıyla yapılan LSD post hoc testi sonuçlarına göre çalışan sayısı 21-30 kişi ve 31-50 ve kişi olan işletmelerdeki çevreyle ilgili yaklaşımlar puanı, çalışan sayısı 1-20 kişi ve 51-100 kişi olan işletmelerin puanlarına göre anlamlı düzeyde daha yüksektir. Çevre muhasebesinin önemi ile ilgili yaklaşım puanlarının işletmedeki çalışan sayısına göre anlamlı farklılık göstermediği $(\mathrm{p}>0,05)$ tespit edilmiştir.

Tablo 6. Ölçek Puanlarının İşletmenin Büyüklüguüne Göre Karşılaştırılmasına Ait ANOVA Testi Sonuçları

\begin{tabular}{|c|c|c|c|c|c|c|c|}
\hline \multirow{2}{*}{\multicolumn{2}{|c|}{ Ölçekler }} & \multicolumn{6}{|l|}{ İşletme } \\
\hline & & Büyüklüğg̈ü & $\mathbf{n}$ & $\overline{\mathbf{x}}$ & SS & $\mathbf{F}$ & $\mathbf{p}$ \\
\hline \multirow{3}{*}{$\begin{array}{l}\text { Çevreyle } \\
\text { Yaklaşımlar }\end{array}$} & \multirow{3}{*}{ İlgili } & A-Küçük & 15 & 4,01 & 0,54 & \multirow{3}{*}{1,23} & \multirow{3}{*}{0,295} \\
\hline & & B-Orta & 81 & 4,23 & 0,53 & & \\
\hline & & C-Büyük & 16 & 4,12 & 0,55 & & \\
\hline \multicolumn{2}{|l|}{ Çevre } & A-Küçük & 15 & 3,69 & 0,42 & \multirow{3}{*}{1,54} & \multirow{3}{*}{0,220} \\
\hline \multicolumn{2}{|c|}{ Muhasebesinin } & B-Orta & 81 & 3,90 & 0,43 & & \\
\hline $\begin{array}{l}\text { Önemine } \\
\text { Yaklaşımlar }\end{array}$ & İlişkin & C-Büyük & 16 & 3,89 & 0,46 & & \\
\hline
\end{tabular}


Tablo 6'daki ölçek puanlarının işletmenin büyüklüğüne göre karşılaştırmasına ait tek yönlü varyans analizi (ANOVA) sonuçlarına göre, çevreyle ilgili yaklaşım puanlarının işletme büyüklüğüne göre anlamlı farklılık göstermediği $(p>0,05)$ tespit edilmiştir. Çevre muhasebesi ile ilgili yaklaşım puanlarının işletme büyüklüğüne göre anlamlı farklılık göstermediği $(p>0,05)$ tespit edilmiştir.

Tablo 7. Ölçek Puanlarının Çevresel Maliyetlerin Varlığına Göre Karşılaştırılmasına Ait t Testi Sonuçları

\begin{tabular}{|c|c|c|c|c|c|c|}
\hline & Çevresel & & & & & \\
\hline Ölçek & Maliyet & $\mathbf{n}$ & $\overline{\mathrm{x}}$ & SS & $\mathbf{t}$ & $\mathbf{p}$ \\
\hline Çevreyle & Evet & 90 & 4,19 & 0,53 & \multirow{2}{*}{0,10} & \multirow{2}{*}{0,920} \\
\hline Yaklaşımlar & Hayır & 22 & 4,17 & 0,58 & & \\
\hline Cevre Muhasebesinin & Evet & 90 & 3,90 & 0,42 & \multirow[b]{2}{*}{1,34} & \multirow[b]{2}{*}{0,183} \\
\hline $\begin{array}{l}\text { Önemine } \\
\text { Yaklasımlar }\end{array}$ & Hayır & 22 & 3,76 & 0,47 & & \\
\hline
\end{tabular}

Tablo 7'deki ölçek puanlarının çevresel maliyetlerin varlığına göre karşılaştırılmasına ait bağımsız iki örneklem $\mathrm{t}$ testi sonuçlarına göre, çevreyle ilgili yaklaşım puanlarının işletmede çevresel maliyetlerin varlığına göre anlamlı farklılık göstermediği $(p>0,05)$ tespit edilmiştir Çevre muhasebesinin önemi ile ilgili yaklaşım puanlarının işletmede çevresel maliyetlerin varlığına göre anlamlı farklılık göstermediği $(\mathrm{p}>0,05)$ tespit edilmiştir.

Tablo 8. Ölçek Puanlarının Çevresel Sorunları Önlemeye Yönelik Yatırıma Göre Karşılaştırılmasına Ait t Testi Sonuçları

\begin{tabular}{llllllll}
\hline & $\begin{array}{l}\text { Çevresel } \\
\text { Önlemeye }\end{array}$ & $\begin{array}{r}\text { Sorunları } \\
\text { Yönelik }\end{array}$ & & & & & \\
Ölçek & Yatırım & & $\mathbf{n}$ & $\overline{\mathbf{X}}$ & $\mathbf{S S}$ & $\mathbf{t}$ & $\mathbf{p}$ \\
\hline $\begin{array}{l}\text { Çevreyle İlgili } \\
\text { Yaklaşımlar }\end{array}$ & Evet & & 84 & 4,20 & 0,51 & & \\
& Hayır & 28 & 4,13 & 0,60 & 0,62 & 0,535 \\
\hline $\begin{array}{l}\text { Çevre } \\
\text { Muhasebesinin }\end{array}$ & Evet & 84 & 3,95 & 0,36 & & \\
$\begin{array}{l}\text { Önemine İlişkin } \\
\text { Yaklaşımlar }\end{array}$ & Hayır & & & & & 3,30 & $\mathbf{0 , 0 0 1}$ \\
\hline
\end{tabular}

Tablo 8'deki ölçek puanlarının çevresel sorunları önlemeye yönelik yatırıma göre karşılaştırılmasına ait bağımsız iki örneklem t testi sonuçlarına göre, çevreyle ilgili yaklaşım puanlarının çevresel sorunları önlemeye yönelik yatırıma göre anlamlı farklılık göstermediği ( $p>0,05)$ tespit edilmiştir. Çevre muhasebesi ile ilgili yaklaşım puanlarının çevresel sorunları önlemeye yönelik yatırıma göre anlamlı farklılık gösterdiği tespit edilmiştir $(t=3,30 ; p<0,05)$. Çevresel sorunları önlemeye yönelik yatırım yapan işletmelerin çevre muhasebesinin önemi 
ile ilgili yaklaşımlar puanı, çevresel sorunları önlemeye yönelik yatırım yapmayan işletmelerin puanlarına göre anlamlı düzeyde daha yüksektir.

Tablo 9. Ölçek Puanlarının Çevresel Sorunlara Yönelik Yatırımların Nedenine Göre

Karşılaştırılmasına Ait t Testi Sonuçları

\begin{tabular}{|c|c|c|c|c|c|c|}
\hline & Yatırım & & & & & \\
\hline Ölçek & Nedeni & $\mathbf{n}$ & $\overline{\mathrm{X}}$ & SS & $\mathbf{t}$ & $\mathbf{p}$ \\
\hline Çevreyle & Zorunlu & 62 & 4,26 & 0,53 & \multirow{2}{*}{1,78} & \multirow{2}{*}{0,079} \\
\hline Yaklaşımlar & Gönüllü & 22 & 4,04 & 0,42 & & \\
\hline Çevre Muhasebesinin & Zorunlu & 62 & 3,98 & 0,36 & \multirow[b]{2}{*}{1,54} & \multirow[b]{2}{*}{0,128} \\
\hline $\begin{array}{l}\text { Önemine } \\
\text { Yaklaşımlar }\end{array}$ & Gönüllü & 22 & 3,85 & 0,35 & & \\
\hline
\end{tabular}

Tablo 9'daki ölçek puanlarının çevresel sorunlara yönelik yatırımların nedenine göre karşılaşıtırılmasına ait bağımsız iki örneklem $t$ testi sonuçlarına göre, çevreyle ilgili yaklaşım puanlarının çevresel sorunlara yönelik yatırımların nedenine göre anlamlı farklılık göstermediği $(p>0,05)$ tespit edilmiştir. Çevre muhasebesinin önemi ile ilgili yaklaşım puanlarının çevresel sorunlara yönelik yatırımların nedenine göre anlamlı farklılık göstermediği $(p>0,05)$ tespit edilmiştir.

Tablo 10: Ölçek Puanlarının Çevresel Sorunlara Yönelik Yatırımlar İçin Mali Destek Alma Durumuna Göre Karşılaştırılmasına Ait t Testi Sonuçları

\begin{tabular}{|c|c|c|c|c|c|c|}
\hline & $\begin{array}{l}\text { Yatırım } \\
\text { İçin Mali }\end{array}$ & & & & & \\
\hline Ölçek & Destek & $\mathbf{n}$ & $\overline{\mathrm{x}}$ & SS & $\mathbf{t}$ & $\mathbf{p}$ \\
\hline Çevreyle & Evet & 21 & 4,11 & 0,54 & & \\
\hline Yaklaşımlar & Hayır & 63 & 4,23 & 0,50 & $-0,90$ & $0,3 / 2$ \\
\hline Çevre Muhasebesinin & Evet & 21 & 3,95 & 0,35 & & \\
\hline $\begin{array}{l}\text { Önemine } \quad \text { İlişkin } \\
\text { Yaklaşımlar }\end{array}$ & Hayır & 63 & 3,95 & 0,37 & $-0,04$ & 0,965 \\
\hline
\end{tabular}

Tablo 10'daki ölçek puanlarının çevresel sorunlara yönelik yatırımlar için mali destek alma durumuna göre karşılaş̧ııılmasına ait bağımsız iki örneklem $t$ testi sonuçlarına göre, çevreyle ilgili yaklaşım puanlarının çevresel sorunlara yönelik yatırımlar için mali destek alma durumuna göre anlamlı farkllık göstermediği $(p>0,05)$ tespit edilmiştir. Çevre muhasebesinin önemi ile ilgili yaklaşım puanlarının çevresel sorunlara yönelik yatırımlar için mali destek alma durumuna göre anlamlı farklılık göstermediği $(p>0,05)$ tespit edilmiştir. 
Tablo 11. Ölçek Puanları Arasındaki İlişkiye Ait Pearson Korelasyon Analizi Sonuçları

\begin{tabular}{lll}
\hline Ölçek & $\mathbf{n}$ & $\mathbf{r}$ \\
\hline Çevreyle İlgili Yaklaşımlar & 112 & $0,66^{* *}$ \\
Çevre Muhasebesinin Önemine İlişkin Yaklaşımlar & 112 & \\
\hline
\end{tabular}

Tablo 11'deki ölçek puanları arasındaki ilişkiye ait Pearson korelasyon analizi sonuçlarına göre, çevreyle ilgili yaklaşım puanları ile çevre muhasebesi ile ilgili yaklaşım puanları arasında pozitif yönlü ve anlamlı ilişki tespit edilmiştir $(r=0,66 ; p<0,05)$. Çevresel yaklaşımları yüksek düzeyde benimseyen işletmeler, işletme muhasebesinin çevreden sorumlu olması gerektiği yaklaşımını da yüksek düzeyde benimsemektedir.

\section{SONUÇ}

Küreselleşme ve sanayileşmenin artması ile birlikte işletme kaynaklı çevresel sorunlar artmıştır. İşletmeler faaliyetlerini yürütürken çevresel sorunları önlemeye yönelik yatırımları bir maliyet olarak görmeyerek geleceği kurtarmak adına çeşitli tedbirler alması artık bir zorunluluk haline gelmiştir. İşletme faaliyetlerinin çevre üzerindeki olumsuz etkilerinden sorumlu olan işletme yöneticilerinin büyük çoğunluğu bu etkileri önlemeye yönelik olarak yapacakları çevresel maliyetlerin farkında değillerdir. İşletmelerin başarılı olarak varlığını devam ettirmesi ve rekabet avantajı sağlaması büyük oranda faaliyetlerinin çevreye olan/olası olumsuz etkilerini minimize etmesine ve çevrenin korunmasina yönelik gerekli tedbirleri alarak ve çevresel duyarlılığı ilgili taraflara raporlamasına bağlıdır. Çevre muhasebesi uygulamalarının hedefi, ürünün tasarım aşamasından itibaren tüm yaşam eğrisi dikkate alınarak, çevreye duyarlı ürünlerin üretilmesi sürecinde alınan tedbirlerin genel olarak maliyetlere etkisini cevaplayabilmesidir. Çevre muhasebesi uygulamasındaki güçlüklerin aşılması çevre muhasebenin etkinliğini daha da artıracaktır.

Araştırma sonuçlarına göre; Ordu ili ve merkez ilçelerindeki organize sanayi bölgesinde faaliyet gösteren işletme yöneticilerinin çevresel yaklaşımları ve çevre muhasebesinin önemine ilişkin yaklaşımları yüksek düzeyde benimsedikleri tespit edilmiştir. İşletmelerin çevre muhasebesinin önemine iliş̧in yaklaşımları gıda ve diğer sektörde faaliyet gösteren işletmelerde, gıda sektörüne göre anlamlı düzede yüksek olduğu tespit edilmiştir. Çevreyle ilgili yaklaşımlarına baktığımızda çalışan sayısı 21-30 ve 31-50 kişi olan işletmelerde yüksek olduğu tespit edilmiştir. Çevresel sorumları önlemeye yönelik yatırım yapan işletmelerin çevre muhasebesinin önemine ilişkin yaklaşımları çevresel sorunları önlemeye yönelik yatırım yapmayan işletmelere göre anlamlı düzeyde daha yüksektir. İşletmelerin çevre sorunlarını önlemeye yönelik yatııımları yapmak üzere mali destek alıp almama durumlarına göre çevresel yaklaşımlarında anlamlı farklılık olmadığı tespit edilmiştir. Son olarak işletmelerin çevresel yaklaşımları ile çevre muhasebesine verdikleri önem arasında pozitif yönlü ve anlamlı ilişki tespit edilmiştir.

İşletme yöneticilerine çevresel sorumluluk ve çevrenin önemini anlatmaya yönelik çalışmalar yapılmalı ve çevreyi korumaya yönelik faaliyetleri belirli aralıklarla denetlenmeli ve eksikliklerin giderilmesine yönelik yaptırımlar uygulanmalıdır. 


\section{KAYNAKLAR}

Alagöz, Ali - Yılmaz, Baki (2001), “Çevre Muhasebesi ve Çevresel Maliyetler”, Selçuk Üniversitesi İktisadi ve İdari Bilimler Fakültesi, Sosyal ve Ekonomik Araştırmalar Dergisi, Yıl:1, Sayı: 1-2, ss.147-158.

Akbaş, Halil Emre (2011), "Çevresel Yönetim Muhasebesi: Özellikleri, Unsurları Ve Kullanım Alanları", Muhasebe Bilim Dünyası Dergisi, Sayı :3, ss.29-59.

Alagöz, Ali - İrdiren, Duygu (2013), "Maliyet Muhasebesi Bakış Açısı İle İşletmelerde Çevre Maliyetleri ve Yönetimi”, Sosyal ve Ekonomik Araştırmalar Dergisi, Cilt:13, Sayı:26, ss. $424-449$.

Akatay, Ayten - Aslan, Şebnem (2008), "Yeşil Yönetim ve İşletmeleri ISO 14001 Sertifikası Almaya Yönelten Faktörler", Dokuz Eylül Üniversitesi Sosyal Bilimler Enstitüsü Dergisi, Cilt: 10, Sayı:1, ss. 313-339.

Aslanertik, Banu Esra - Özgen, Işsl (2007), "Otel İşletmelerinde Çevresel Muhasebe”, İşletme Fakültesi Dergisi, Cilt:8, Sayı:2, ss.163-179.

Özay Baltacı, Füsun (2009), "Çevre Maliyetleri ve Bir Sanayi İşletmesinde Uygulama", Kocaeli Üniversitesi Sosyal Bilimler Enstitüsü (Yayımlanmamış Yüksek Lisans Tezi). Kocaeli.

Burritt, Roger L. (2004), "Environmental Management Accounting: Roadblocks on the Way to the Green and Pleasant Land", Business Strategy and The Environment 14 (1): pp.13-32.

Cavlı, Melek (2009), "Şirket Çevreciliği Ekseninde Türkiye'deki Şirketlerin Çevresel Sorumlulukları", Yüksek Lisans Tezi, Ankara Üniversitesi, Sosyal Bilimler Enstitüsü, Ankara.

Çelik, Muhsin (2007), "Çevreye Duyarlı Muhasebe", Muhasebe ve Finansman Dergisi, Sayı: 33, ss.151-161.

Çetin, Eray (2011), "Üretim İşletmelerinin Sosyal Bir Sorumluluk Olarak Çevre Muhasebesine Verdikleri Önem: Mersin-Tarsus Organize Sanayi Bölgesi‘nde Faaliyet Gösteren Üretim İşletmeleri Üzerinde Bir Uygulama”, Yüksek Lisans Tezi, Karamanoğlu Mehmet Bey Üniversitesi Sosyal Bilimler Enstitüsü, Karaman.

Deniz, Tuğba - Türker, Ahmet (2012), "Çevresel Muhasebe ve Uygulamaları", Journal of the Faculty of Forestry, Istanbul University, Cilt:62, Say1:1, ss.115-132.

Dura, Cihan (1991), "Çevre Sorunları ve Ekonomi", Türkiye Çevre Sorunları Vakfı Yayınları (Çevre üzerine), Ankara.

Gale, Robert (2006), "Environmental Management Accounting as a Refl exive Modernization Strategy in Cleaner Production" Journal of Cleaner Production, Volume:14, Issue:14, pp:1228-1236. 
Gönel, Feride - Atabarut, Tamer (2005), Şirketlerin Yeni Yönetim Aracı: Çevresel Muhasebe, TÜSİAD Yayın No: 2005-06/404, İstanbul: Lebib Yalkın Yayımları.

Güvemli, Oktay - Gökdeniz, Ümit (1996), “Çevre Muhasebesindeki Gelişmeler”, Muhasebe Öğretim Üyeleri Bilim ve Dayanışma Vakfı, Muhasebe Bilim Dünyası Dergisi, Sayı:4, ss:23-24.

Jasch, Christine (2003), "The Use of Environmental Management Accounting (EMA) for Identifying Environmental Costs", Journal of Cleaner Production, Volume.14, Issue.6, pp:667-676.

Kaya, Nurullah (2016), “Sürdürülebilir Yönetim Muhasebe Sistemi”, International Journal of Academic Value Studies, Cilt:2, Say1:2, ss.20-35. (ISSN:2149-8598).

Kırlığlu, Hilmi - Can, Ahmet Vecdi (2006), "Çevresel Muhasebede Kavramsal Tartışmaların Gelişimi ve Analizi”, Muhasebe ve Finansman Dergisi, Cilt.32, ss.61- 71.

Korukoğlu, Ayşen (2011), "İşletmelerde Çevre Muhasebesi: İzmir İli Uygulaması", Ege Akademik Bakış, Cilt.11, Sayı.1, ss. 81-89.

Korukoğlu, Ayşen (2014), “İşletmelerin Çevre Muhasebesi Konularına Yaklaşımlarının Analizi”, Ege Akademik Bakış, Cilt 14, Sayı 3, ss. 481-491.

Lazol, İbrahim - Muğal, Elif - Yücel, Yener (2008), "Sürdürülebilir Bir Çevre İçin Çevre Muhasebesi ve KOBI'lere Yönelik Bir Araştırma”, Muhasebe ve Finansman Dergisi, Sayı 38, ss. 56-69.

Orhan, M. Suphi - Ăğ, Ali Rıza (2017), "Üretim İşletmelerinin Çevre Muhasebesine Verdikleri Önem Düzeyi: Erzurum, Erzincan, Bayburt Bölgesinde Bir Araştırma", Muhasebe ve Finansman Dergisi, Sayı 74, ss.1-14.

Özbirecikli, Mehmet (2002), Çevre Muhasebesi, Naturel Kitap ve Yayıncılık, Ankara.

Soylu, Yasemin - İleri, Hüseyin (2009), "Çevre Muhasebesi ve Çevre Maliyetlerinin Üretim Maliyetlerine Etkileri”, Selçuk Üniversitesi Sosyal Bilimler MYO Dergisi, Cilt 12, Sayı 1-2, ss. 390-322.

Xiaomei, Li (2004), "Theory and Practice of Environmental Management Accounting" International Journal of Technology Management \& Sustainable Development, Volume 3, Issue 1, pp. 47-57.

Yakhou, Mehenna - Dorweiler, Vernon P. (2004), "Environmental Accounting: An Essential Component of Business Strategy", Business Strategy and the Environment, Volume13, pp. 65-77.

Yüksel, Harun (2003), "İşletmelerin Çevreye Duyarlı Üretim Faaliyetlerinin Ampirik Bir Çalışma İle Değerlendirilmesi”, Endüstri Mühendisliği Dergisi, Cilt 14, Sayı 2, ss. 21 32 . 
Yörük, Nevin (1999), “Çevre Muhasebesi”, İktisat, İşletme ve Finans Dergisi, Sayı 154, ss. $68-72$. 
